\title{
Characterization of Acid-Aluminium Sensitive Mutants of Soybean Symbiont Bradyrhizobium japonicum Generated by Transposon Mutagenesis
}

\author{
ARIS TRI WAHYUDI*, ANDINI PURNAWIJAYA, DINI NURDIANI, AND TEDJA-IMAS \\ Department of Biology, Faculty of Mathematics and Natural Sciences, Institut Pertanian Bogor, \\ Darmaga Campus, Bogor 16680, Indonesia
}

\begin{abstract}
Acid-aluminium sensitive mutants of symbiotic bacterium Bradyrhizobium japonicum BJ11 (designated as AAS11) and KDR15 (designated as AAS15) were constructed by mini-Tn5 transposon mutagenesis to study genes involved in acid-aluminium tolerance (AAT) in B. japonicum. Transposon delivery was carried out through conjugation between $B$. japonicum strains as recipients and Escherichia coli S17-1 (ë pir) carrying pUTminiTn $5 \mathrm{Km} 1$ as a donor strain. The result showed that frequency of transconjugation was in the range of $6.7 \times 10^{-7}$ to $7.1 \times 10^{-6}$ cell per recipients. AAS11 and AAS15 mutants did not grow on Ayanaba media (pH 4.5) containing $50 \mu \mathrm{M}$ Aluminium. These mutants remained able to form root nodules of Siratro (Macroptilium arthropurpureum) plants revealing genes interrupted by transposon which were responsible for acid-Al tolerance did not correlate with the nodulation genes. Strains tolerant to acid-aluminium and their mutants with a wild type sensitive to acidaluminium were characterized by accumulating phosphate and aluminium absorption. Compared to the wild type acid-aluminium tolerant $B$. japonicum, there was approximately a three- to eight-times decrease in phosphate accumulation and a five- to seven-times increase in aluminium absorption by these mutants. These results suggest that aluminium and phosphate contents in the bacterial cells may be involved in mechanisms of acid-Al tolerance of $B$. japonicum grown in acid-aluminium stress conditions.
\end{abstract}

Key words: Bradyrhizobium japonicum, acid-aluminium tolerance, transposon mutagenesis, aluminium absorption, phosphate intracellular

Bradyrhizobium japonicum is one of the nitrogen fixing bacteria which can symbiose with either soybean or siratro plants through root nodule formation. Most of the nitrogen source required by soybean plants can be provided by this symbiosis. However, the high solubility of aluminium in acid soils can poison root nodule bacteria (Flis et al. 1993). This condition will influence symbiosis between root nodule bacteria and the soybean plant. Soil acidity can induce nitrogen deficiency in soybeans by preventing root nodule formation. Low levels of phosphorus, calcium, and molybdenum, and high levels of aluminium, iron, and manganese are important factors of soil acidity and can be toxic for plants and root nodule bacteria. Soil acidity generally increases the lag time or slows the growth rate of bacteria (Keyser and Munns 1979). To date, there are several reports revealing that some nitrogen fixing bacteria can survive on media with a pH 4.5 containing $50 \mu \mathrm{M} \mathrm{Al}, 200 \mu \mathrm{M} \mathrm{Mn}, \mathrm{Ca}$ $50 \mu \mathrm{M}$, and $5 \mu \mathrm{M}$ PO4- (Ayanaba et al. 1983; Endarini et al. 1995; Wahyudi et al. 1998).

Reports on the acid-Al tolerant bradyrhizobial or rhizobial strains exerting tolerance to acid-Al are not fully understood. Acid-Al tolerance appears to be related with amounts of phosphate supplemented in the media or its availability in the soil (Flis et al. 1993). Cellular phosphate has been shown in many different bacteria as one of the mechanisms to counter the effects of metal toxicity (Keasling and Hupf 1996; Alvarez and Jerez 2004). Gemell et al. (1993) and Watkin et al. (1997) reported that increasing the phosphate and calcium concentration in the media at low $\mathrm{pH}$ will increase the growth of the root nodule bacteria, bradyrhizobial, and rhizobial

${ }^{*}$ Corresponding author, Phone/Fax: +62-251-622833, E-mail: aristri2003@yahoo.com strains. Increasing phosphate up to $100 \mu \mathrm{M}$ was able to encounter toxicity of aluminium $(50 \mu \mathrm{M})$ at $\mathrm{pH} 5.5$ to $B$. japonicum in the soil (Mukherjee and Asanuma 1998).

A transposon is a DNA fragment which can transpose from one site to another site in the genome. One of the applications of the transposon is to mutate a gene (mutagenesis) and determine the physical location of genes of interest (Guilhabert et al. 2001). In this study, the transposon mini-Tn5Km1 (De Lorenzo et al. 1990) was used to generate acid-Al sensitive mutants of $B$. japonicum. This transposon has a relatively high frequency of transposition, low insertionally specificity, and can be expressed in most gram negative bacteria. Other advantages of the transposon mini- $\operatorname{Tn} 5 \mathrm{Km} 1$ is the availability of a detailed genetic and physical map.

This study demonstrates the production of acidaluminium sensitive mutants of $B$. japonicum generated by transposon mutagenesis as defined in root nodule formation, cellular phosphate content, and aluminium absorption in relation with genes interrupted by the transposon which are involved in acid-aluminium tolerance.

\section{MATERIALS AND METHODS}

Bacterial Strains, Media, and Growth Conditions. Two, acid-Al tolerant $B$. japonicum strains, BJ11 and KDR15 (Imas 1994), were routinely grown in yeast extract mannitol agar (YMA) (mannitol $10 \mathrm{~g} \mathrm{l}^{-1}, \mathrm{~K}_{2} \mathrm{HPO}_{4} 0.5 \mathrm{~g} \mathrm{l}^{-1}, \mathrm{MgSO}_{4} \cdot 7 \mathrm{H}_{2} \mathrm{O}$ $0.2 \mathrm{~g} \mathrm{l}^{-1}, \mathrm{NaCl} 0.2 \mathrm{~g} \mathrm{l}^{-1}$, yeast extract $5 \mathrm{~g} \mathrm{l}^{-1}$ ) supplemented with Congo Red (CR) $0.0025 \%(\mathrm{w} / \mathrm{v})$ at room temperature. Acid$\mathrm{Al}$ sensitive B. japonicum strain (BJ13) was used as a control. Escherichia coli $\mathrm{S} 17-1$ ( $\lambda$ pir), which carries 
pUTmini-Tn5Km1 (de Lorenzo et al. 1990), was routinely grown on Luria agar (LA) (tryptone $5.0 \mathrm{~g} \mathrm{l}^{-1}, \mathrm{NaCl} 10 \mathrm{~g} \mathrm{l}^{-1}$, yeast extract $5.0 \mathrm{~g} \mathrm{l}^{-1}$, agar $15 \mathrm{~g} \mathrm{l}^{-1}$ ) supplemented with kanamycin $\left(50 \mu \mathrm{g} \mathrm{ml}^{-1}\right)$ and ampicillin $\left(50 \mu \mathrm{g} \mathrm{l}^{-1}\right)$ at $37^{\circ} \mathrm{C}$. The siratro plant was used for root nodulation experiments.

Antibiotic Resistance Test. Acid-Al tolerant $B$. japonicum strains BJ11 and KDR15 and E. coli S17-1 ( $\lambda$ pir $)$ were tested for their antibiotic resistance. Four antibiotics were used in the following concentrations: Kanamycin (Km) $\left(50 \mu \mathrm{g} \mathrm{ml}^{-1}\right)$, Rifampicin (Rif) $\left(50 \mu \mathrm{g} \mathrm{ml}^{-1}\right)$, Ampicilin (Amp) $\left(50 \mu \mathrm{g} \mathrm{ml}^{-1}\right)$, and Tetracyclin (Tc) $\left(50 \mu \mathrm{g} \mathrm{ml}^{-1}\right)$. All strains were plated on suitable media supplemented with each antibiotic. This work was carried out to determine selectable markers that will be used in transposon mutagenesis experiments.

Transposon Mutagenesis and Screening of Acid-Al Sensitive Mutants. The recipients, acid-Al tolerant $B$. japonicum BJ11 and KDR15, were grown on YMA + CR $(0.0025 \% \mathrm{~b} / \mathrm{v})+\operatorname{Rif}\left(50 \mu \mathrm{g} \mathrm{ml}^{-1}\right)$. All cultures were incubated aerobically at room temperature agitated at $140 \mathrm{rpm}$ for $60-72$ h. The donor, E. coli S17-1 ( $\lambda$ pir), was grown on LB $+\mathrm{Km}$ (50 $\left.\mu \mathrm{g} \mathrm{ml}^{-1}\right)+\operatorname{Amp}\left(50 \mu \mathrm{g} \mathrm{ml}^{-1}\right)$ and incubated aerobically with agitation at $140 \mathrm{rpm}$ for $18-20 \mathrm{~h}$ at $37^{\circ} \mathrm{C}$. The transposon mini-Tn $5 \mathrm{Km} 1$ carried by $E$. coli $\mathrm{S} 17-1$ ( $\lambda$ pir) was transferred to recipients by diparental mating conjugation in which the ratio of donor and recipient cells was 1:1 $\left(\sim 10^{8}\right.$ cells $\left.\mathrm{ml}^{-1}\right)$. All matings were carried out on membrane filters $(0.45 \mu \mathrm{m})$ placed on LA modified media (LA omitting $\mathrm{NaCl} 1.0 \mathrm{~g} \mathrm{l}^{-1}$ ) without antibiotic, and incubated for 12, 18, and $24 \mathrm{~h}$ at room temperature. The transconjugants were plated on YMA + $\mathrm{CR}(0.0025 \% \mathrm{w} / \mathrm{v})+\mathrm{Km}\left(50 \mu \mathrm{g} \mathrm{ml}^{-1}\right)+\operatorname{Rif}\left(50 \mu \mathrm{g} \mathrm{ml}^{-1}\right)$. Screening of acid-aluminium sensitive mutants of $B$. japonicum was performed on Ayanaba media $(\mathrm{pH} 4.5 ; 50 \mu \mathrm{M}$ Al) (Ayanaba et al. 1983). Colonies which grew on YMA + CR $(0.0025 \% \mathrm{w} / \mathrm{v})+\mathrm{Km}\left(50 \mu \mathrm{g} \mathrm{ml}^{-1}\right)+\operatorname{Rif}\left(50 \mu \mathrm{g} \mathrm{ml}^{-1}\right)$ but which failed to grow on Ayanaba media were choosed for further analysis.

Root Nodulation Experiment. All acid-Al sensitive mutants of B. japonicum and the wild type were tested for root nodulation on siratro plants. Each of these mutants were inoculated on siratro (Macroptilium atropurpureum) plants at a concentration of $10^{6}$ cells $\mathrm{ml}^{-1}$. The siratro was planted in $25 \mathrm{~mm}$ diameter $\times 200 \mathrm{~mm}$ long reaction tubes using the medium as described by Speidel and Wollum (1980) and grown in a green-house. Root nodule formation was examined from day 7 to day 30 after inoculation.

Cellular Phosphate Content. Mutants and the wild type were grown on phosphate media as described by Keyser and Munns (1979). All cultures were incubated at room temperature and agitated at $60 \mathrm{rpm}$. When cells reached a density until gave an OD620 reading of $0.7\left(\sim 10^{9}\right.$ cell ml $\left.{ }^{-1}\right)$, cells were pelleted $\left(10,000 \mathrm{rpm}, 15 \mathrm{~min}, 4{ }^{\circ} \mathrm{C}\right)$ and the subsequent pellet was then incubated with $10 \mathrm{ml}$ of $25 \% \mathrm{HCl}$ for $24 \mathrm{~h}$ and then diluted in sterile distilled water to give a total volume of $25 \mathrm{ml}$. A $2.0 \mathrm{ml}$ aliquot was then added to $2 \mathrm{ml}$ $\mathrm{HNO}_{3}$ and $1 \mathrm{ml}$ molybdate-vanadate solution and incubated for $20 \mathrm{~min}$. Total phosphate content was assayed spectrophotometrically using the molybdate-vanadate method at $\lambda 420 \mathrm{~nm}$ (Mukherjee and Asanuma 1998). The total phosphate content on BJ13 was also measured as a control.
Analysis of Aluminium Absorption. Acid-Al sensitive mutants of B. japonicum and the wild type were grown on phosphate media as described by Keyser and Munns (1979). All cultures were agitated at $60 \mathrm{rpm}$ and incubated at room temperature. When cells reached a density which gave an $\mathrm{OD}_{620}$ reading of 0.7 (ca $10^{9} \mathrm{cells} \mathrm{ml}^{-1}$ ), cells were pelleted $\left(10,000 \mathrm{rpm}, 15 \mathrm{~min}, 4^{\circ} \mathrm{C}\right)$ and then resuspended in $50 \mathrm{ml}$ sterilized 2-(N-morpholino) ethanesulfonic acid (MES, pH 5.4) buffer containing $50 \mu \mathrm{M} \mathrm{Al}$ for $30 \mathrm{~h}$ (Mukherjee and Asanuma 1998). After the relevant periods, cells were pelleted $\left(10,000 \mathrm{rpm}, 15 \mathrm{~min}, 4^{\circ} \mathrm{C}\right)$. Aluminium was assayed using an Atomic Absorption Spectrophotometer at $\lambda 303 \mathrm{~nm}$. The total aluminium absorption on BJ13 was also measured as a control.

\section{RESULTS}

Antibiotic Resistance Test. All acid-Al tolerant $B$. japonicum strains showed resistance to ampicilin and rifampicin at $50 \mu \mathrm{g} \mathrm{ml}^{-1}$. On the other hand, E. coli showed resistance to kanamycin and ampicilin at $50 \mu \mathrm{g} \mathrm{ml}^{-1}$ (Table 1). The ability of $E$. coli to grow on LA media supplemented by kanamycin and ampicilin was due to the fact that this bacterium carried the pUTmini-Tn5Km1 component which has gene resistance to kanamycin (Km1) and ampicilin (Amp). Therefore, Kanamycin and Rifampisin were choosen as a selectable markers of the $B$. japonicum transconjugant generated by transposon mutagenesis.

Transposon Mutagenesis. Transposon mini-Tn5Km1 was transferred to the recipient $B$. japonicum by conjugation diparental mating. This generated $B$. japonicum mutants which were resistant to kanamycin. The plasmid pUTminiTn5Km1 has origin of replication (ori) from pR6K. It can replicate only in a host providing the pir factor (protein initiation of replication). Transfer of $\mathrm{Km} 1$ into B. japonicum was achieved by using the mob gene of the plasmid RP4 which was driven by the products of the tra gene provided in trans on the $E$. coli $\mathrm{S} 17-1$ ( $\lambda$ pir) chromosome. Depending on the strains, the frequency of transconjugation varied between $6.7 \times 10^{-7}$ to $7.1 \times 10^{-6}$ per recipient (Table 2 ). The

Table 1 Growth of Bradyrhizobium japonicum and Escherichia coli on media containing antibiotics

\begin{tabular}{lcccc}
\hline \multirow{2}{*}{ Strain } & \multicolumn{4}{c}{ Antibiotic $\left(\mu \mathrm{g} \mathrm{ml}^{-1}\right)$} \\
\cline { 2 - 5 } & Tc 50 & Rif 50 & Ap 50 & Km 50 \\
\hline BJ11 & + & + & + & - \\
KDR15 & + & + & + & - \\
BJ13 & + & + & + & - \\
E.c & - & - & + & + \\
\hline BJ11:
\end{tabular}

BJ11: Bradyrhizobium japonicum BJ11, KDR15: Bradyrhizobium japonicum KDR15, BJ13: Bradyrhizobium japonicum BJ13, E.c: Escherichia coli S17-1 ( $\lambda$ pir), +: grew, -: did not grow.

Table 2 Frequency of transconjugation of transposon MiniTn5Km1 from $E$. coli $\mathrm{S} 17-1$ ( $\lambda$ pir) to acid-Al tolerant $B$. japonicum as a function of mating time

\begin{tabular}{ccc}
\hline \multirow{2}{*}{$\begin{array}{c}\text { Bacterial conjugation } \\
\text { time }(\mathrm{h})\end{array}$} & \multicolumn{2}{c}{$\begin{array}{c}\text { Frequency of transconjugation }{ }^{\mathrm{a}} \\
\text { B. japonicum } \times \text { E. coli } \mathrm{S}-17-1(\lambda \text { pir })\end{array}$} \\
\cline { 2 - 3 } 12 & $6.7 \times 10^{-7}$ & KDR15 \\
\hline 18 & $1.1 \times 10^{-6}$ & $5.4 \times 10^{-6}$ \\
24 & $7.1 \times 10^{-6}$ & $6.3 \times 10^{-6}$ \\
\hline
\end{tabular}

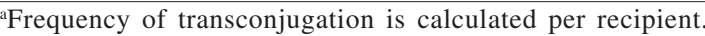


highest frequency of transconjugation was obtained using a mating time as long as $24 \mathrm{~h}$.

Screening of Acid-Al Sensitive Mutants and Root Nodule Formation. Acid-Al sensitive mutants are transconjugants which grow on YMA + CR $(0.0025 \% \mathrm{w} / \mathrm{v})+\mathrm{Km}\left(50 \mu \mathrm{g} \mathrm{ml}^{-1}\right)+$ Rif $\left(50 \mu \mathrm{g} \mathrm{ml}^{-1}\right)$, but which failed to grow on Ayanaba media ( $\mathrm{pH} 4.5, \mathrm{Al} 50 \mathrm{mM})$. One acid-Al sensitive mutant generated from BJ11 (designated AAS11) and one from KDR15 (designated AAS15) were obtained. All mutants and their wild type afforded the ability to form root nodules on siratros (Table 3).

Cellular Phosphate Content. Total cellular phosphate declined in acid-Al sensitive mutants of B. japonicum when

Table 3 Results of root nodulation of the siratro plant by strains of Bradyrhizobium japonicum (wild type and mutant)

\begin{tabular}{lccc}
\hline \multirow{2}{*}{ Strain } & \multicolumn{3}{c}{ No. nodule formed } \\
\cline { 2 - 4 } & Day & Number/plant & Position \\
\hline Wild type & & 4 & 3 PR/1 SR \\
BJ 11 & 15 & 4 & 3 PR/1 SR \\
KDR 15 & 15 & & \\
Mutan & & 6 & 6 PR \\
AAS 11 & 15 & 5 & 5 PR \\
AAS 15 & 13 & &
\end{tabular}

PR: Primary root, SR: Secondary root.

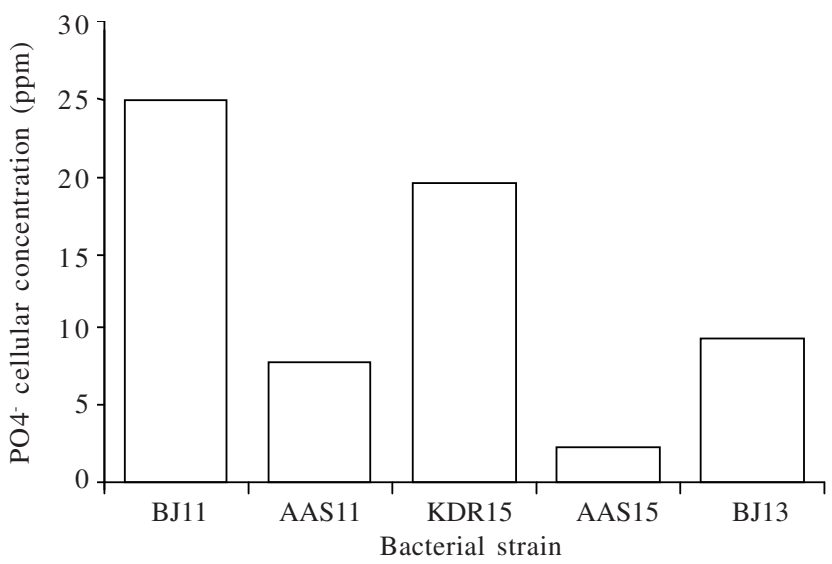

Fig 1 Cellular phosphate content of wild type acid-Al $B$. japonicum BJ11 and its mutant (AAS11), wild type B. japonicum KDR15 and its mutant (AAS15) and wild type acid-Al sensitive $B$. japonicum BJ13, grown on phosphate media $\mathrm{pH} 6.4$.

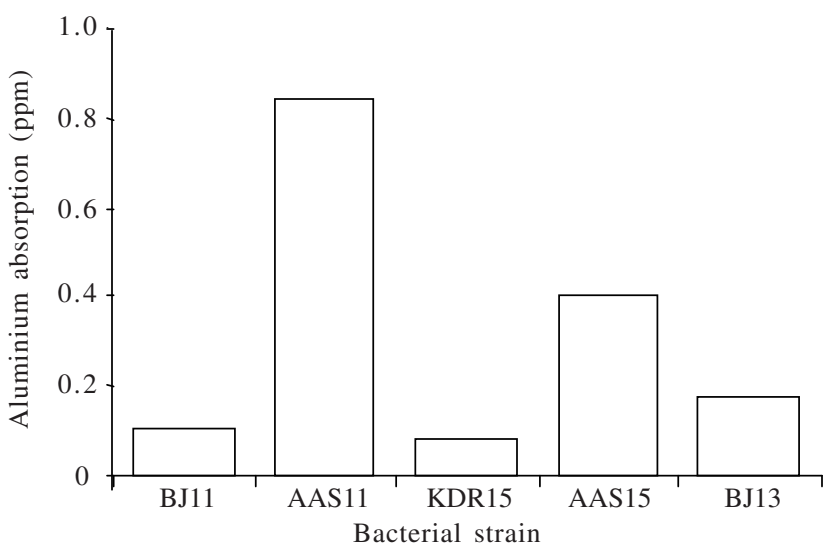

Fig 2 Absorption of aluminium by wild type acid-Al B. japonicum BJ11 and its mutant (AAS11), B. japonicum KDR15 and its mutant (AAS15) and wil type acid-Al sensitive B. japonicum BJ13, inoculated in MES buffer $\mathrm{pH} 5.4$ containing aluminium $(50 \mu \mathrm{M})$. compared to their wild type. The amounts of total cellular phosphate of AAS11 were 3X lower than its wild type, and relatively lower than BJ13. Similarly, the total cellular phosphate of AAS 15 mutant was $8 X$ lower than its wild type and $4 \mathrm{X}$ lower than BJ13 (Fig 1).

Aluminium Absorption Analysis. Aluminium was found in mutants (AAS11 and AAS15), the wild type acid-Al toleran BJ11 and KDR15, and the wild type acid-Al sensitive strain BJ13. However, the amounts of Al absorbed by AAS11, AAS15, and BJ13 were higher than those in the cells of the acid-Al tolerant strains. The amount of aluminium absorbed by AAS 11 was $7 \mathrm{X}$ higher than for its wild type, whereas the mutant AAS15 absorbed Al 5X higher than its wild type. The amounts of $\mathrm{Al}$ were about two 2X in the cells of the BJ13 strain than in the cells of the acid-Al tolerant strains (Fig 2).

\section{DISCUSSION}

Both of the strains BJ11 and KDR15 grew large watery colonies. Fuhrmann (1990) divided B. japonicum into three colony types which are large watery, large mucoid, and small dry. Ayanaba et al. (1983) reported that colony types appeared to influence tolerance of the acid-Al stress on soybean rhizobia. Strain that formed small dry, pinpoint colonies were more sensitive to acd-Al than those which formed large and 'gummy' colonies.

The transposon mini-Tn5Km1 from plasmid pUTminiTn5Km1 was successfully introduced into acid-Al tolerant B. japonicum strains. The suicide plasmid, pUTmini-Tn5Km1, contains the transposase gene in cis configuration outside of the transposable elements. This prevents secondary transposition when the plasmid is lost from the cell (de Lorenzo et al. 1990). The highest frequency of transconjugation obtained was about $7.1 \times 10^{-6}$ per recipient, with a mating time as long as $24 \mathrm{~h}$ at $1: 1$ ratio between $E$. coli S17-1 ( $\lambda$ pir) and B. japonicum. This frequency is higher than $B$. japonicum $\left(5.7 \times 10^{-9}\right)$ using mini-Tn5Km1 for mutagenesis with a 1:10 ratio between donor and recipients (Wahyudi et al. 1998). These results indicate that mating time and donor:recipient ratio are affecting conjugation efficiency. The differences in frequencies between strains may have been due to the inherent properties of the bacterial cell systems. Similar responses have also been reported by Wahyudi et al. (1998). DNA Polymerase I, membrane filters, and termination transcription factor can also influence transposition events (Berg 1989).

One acid-Al sensitive mutant generated from BJ11 (AAS11) and one mutant generated from KDR15 (AAS15) were obtained. The inability of mutants to grow on Ayanaba media is due to the transposon mini-Tn5 being inserted into the $B$. japonicum chromosome, especially in the genes involved in acid-Al tolerance. Transposon mutagenesis on $R$. meliloti WSM419 has also been reported by Goss et al. (1990). These authors observed genes that controlled acid tolerance (act). The disruption of act genes resulted in $R$. meliloti WSM419 not being able to maintain its internal $\mathrm{pH}$ when grown on acid media. Riccillo et al. (2000) reported that $g s h$ gene (gene for glutamine synthetase) was presumed to play an important role for acid tolerance on $R$. tropici CIAT899. Tucker et al. (2002) reported that acid conditions 
will induce genes encoding for glutamate decarboxylase in E. coli MG1655.

Both strains of B. japonicum wild types, BJ11 and KDR15, and their mutants, AAS11 and AAS15, were able to perform root nodulation on siratro plant. The ability of B. japonicum mutants to form root nodules on these plants indicates that the genes for nodulation (nod) have not been affected by inactivation of the genes involved in acid-Al tolerance in $B$. japonicum.

The amounts of total cellular phosphate were larger in the acid-Al tolerant strains when compared with mutants or acid-Al sensitive strains. This result indicates that there was a disruption of the gene for metabolising phosphate. Aluminium was able to enter the cells of tolerant, sensitive, and mutants strains, but the amount accumulated intracellularly was less in the tolerant strains. Johnson and Wood (1990) reported that the absorption of aluminium by cells of both acid-Al- tolerant and -sensitive strains took place however amounts of $\mathrm{Al}$ absorbed by the sensitive strains was $2 \mathrm{X}$ higher than for the tolerant strains. Thus, $\mathrm{Al}$ tolerant strains appeared to have a mechanism to protect the cells by limiting the uptake of $\mathrm{Al}$ from the culture solution. The differences among the strains in their ability to store phosphate internally and use it under adverse conditions could be one of the determining factors to acid-Al stress tolerance or sensitivity (Mukherjee and Asanuma 1998). It seems that available phosphate plays a major role in detoxification of Al lost intra- and extra-cellularly.

There are reports on the role of phosphate metabolism and metal detoxification in microbial systems. Alvarez and Jerez (2004) reported on the role of polyphosphate on copper tolerance in Acidithiobacillus ferrooxidans. They propose that one of mechanisms for heavy metal tolerance involved the hydrolysis polyphosphate and the formation of metalphosphate complexes which are then transported out of the cell. Keasling and Hupf (1996) demonstrated that not only formation, but also the hydrolysis of polyphosphate play a significant role in detoxification of cadmium in E. coli. They also found that two enzymes i.e. polyphosphate kinase and polyphosphatase were involved in the detoxification of cadmium (Keasling and Hupf 1996). The same hypothesis was proposed by Remonsellez et al. (2006) who showed that the ability to accumulate and hydrolyze polyphosphate may play an important role for a copper tolerance mechanism in members of genus Sulfolobus. Acid conditions also stimulated an increase in intracellular polyphosphate and cellular polyphosphate kinase activity of newly isolated environmental strain Candida humicola (Remonsellez et al. 2006). When the cells were grown at $\mathrm{pH} 5.5$, phosphate removal was found to be 4.5 fold higher than when grown at $\mathrm{pH}$ 7.5. This increase in phosphate removal was associated with an increase in free intracellular polyphosphate (McGrath and Quinn 2000). Mukherjee and Asanuma (1998) reported that in $\mathrm{Al}$ tolerant strains, cellular absorption of $\mathrm{Al}$ was related positively to the release of phosphate from the cells and the accumulation of intracellular phosphate (Pi). From our results it is clear that the mutants, AAS11 and AAS15 showed a weaker ability to store phosphate internally and absorbed aluminium more strongly than for their wild type. We therefore conclude that the phosphate metabolic status of bradyrhizobial cells seems to play a major role in countering Al toxicity in acid and in extracellular P-limited conditions.

\section{ACKNOWLEDGEMENT}

This work was supported by a Competitive Grant (Hibah Bersaing) XIII from the Directorate General of Higher Education (DIKTI) of the Republic of Indonesia (2005) to Aris Tri Wahyudi. We are therefore grateful for this funding and support of this research.

\section{REFERENCES}

Alvarez S, Jerez CA. 2004. Copper ions stimulate polyphosphate degradation and phosphate efflux in Acidithiobacillus ferrooxidans. Appl Environ Microbiol 70:5177-5182.

Ayanaba A, Asanuma S, Munns DN. 1983. An agar plate method for rapid screening of Rhizobium for tolerance to acid-alumunium stress. Soil Sci Am J 47:256-258.

Berg DE. 1989. Transposon Tn5. In. Berg DE, Howe MM (eds). Mobile DNA. Washington: ASM Pr.

de Lorenzo V, Herrero M, Jakubzik U, Timmis KN. 1990. Tn5 transposon derivatives for insertion mutagenesis promoter probing and chromosomal insertion of cloned DNA in gramnegative eubacteria. J Bacteriol 172:6568-6572.

Endarini T, Wahyudi AT, Imas T. 1995. Screening of indigenous strains of Bradyrhizobium japonicum for acid-aluminium tolerance. Hayati 2:74-79.

Flis SE, Glenn AR, Dilworth MJ. 1993. The interaction between aluminium and the root nodule bacteria. Soil Biol Biochem 25:403-417.

Furhmann J. 1990. Symbiotic effectiveness of indigenous soybean bradyrhizobia as related to serological, morphological, rhizobitoxine and hydrogenase phenotypes. Appl Environ Microbiol 56:224-229.

Gemell LG, Roughley RJ, Reed ML, Hartley EJ. 1993. Screening of Rhizobium leguminosarum Bv. Trifolii for adaptation to acid and neutral soils using a selective agar medium. Soil Biol Biochem $25: 1463-1464$

Goss TJ, O’Hara GW, Dilworth MJ, Glenn AR. 1990. Cloning, characterization, and complementation of lesions causing acid sensitivity in Tn5-induced mutants of Rhizobium meliloti WSM419. J Bacteriol 172:5173-5179.

Guilhabert MR, Hoffman LM, Mills DA, Kirkpatrick BC. 2001. Transposon mutagenesis of Xylella fastidiosa by electroporation of Tn5 synaptic complexes. Am Phytopathol Soc 14:701-706.

Imas T, Wahyudi AT, Tjahjoleksono A, Saraswati R. 1994. Seleksi galur-galur bakteri bintil akar kedelai unggul pada cekaman $\mathrm{pH}$ rendah dan kekeringan. Lembaga Penelitian dan Pengabdian pada Masyarakat (LPPM) IPB Bogor: Laporan penelitian.

Johnson AC, Wood M. 1990. DNA, a possible site of action of alumunium in Rhizobium spp. Appl Environ Microbiol 56:36293633.

Keasling JD, Hupf GA. 1996. Genetic manipulation of polyphosphate metabolism effects cadmium tolerance in Escherichia coli. Appl Environ Microbiol 62:743-746.

Keyser HH, Munns DN. 1979. Tolerance of Rhizobia to acidity, aluminium, and phosphate. Soil Sci Soc Am J 43:519-523.

McGrath JW, Ouinn JP. 2000. intracellular accumulation of polyphosphate by the yeast Candida humicola G-1 in response to acid pH. Appl Environ Microbiol 66:4068-4073.

Mukherjee SK, Asanuma S. 1998. Possible role of cellular phosphate pool and subsequent accumulation of inorganic phosphate of the aluminium tolerance in Bradyrhizobium japonicum. Soil Biol Biochem 30:1511-1516.

Remonsellez F, Orell A, Jerez CA. 2006. Copper tolerance of the thermoacidophilic archaeon Sulfolobus metallicus: possible role of polyphosphate metabolism. Microbiology 152:59-66.

Riccillo PM et al. 2000. Glutathione is involved in environmental stress response in Rhizobium tropici, including acid tolerance. $J$ Bacteriol 182:1748-1753. 
Speidel KL, Wollum AG. 1980. Evaluating of leguminous inoculant quality: a manual. North Carolina State University: Department of Soil Science.

Tucker DL, Tucker N, Conway T. 2002. Gene expression profiling of the $\mathrm{pH}$ response in Escherichia coli. J Bacteriol 184:65516558.
Wahyudi AT, Suwanto A, Imas T, Tjahjoleksono A. 1998. Screening of acid-aluminium tolerant Bradyrhizobium japonicum strains: analysis of marker genes and competition in planta. Aspac $\mathrm{J} \mathrm{Mol}$ Biol Biotechnol 6:13-20.

Watkin ELJ, O'Hara GW, Glenn AR. 1997. Calcium and acid stress interact to affect the growth of Rhizobium leguminosarum Bv. Trifolii. Soil Biol Biochem 29:1427-1432. 